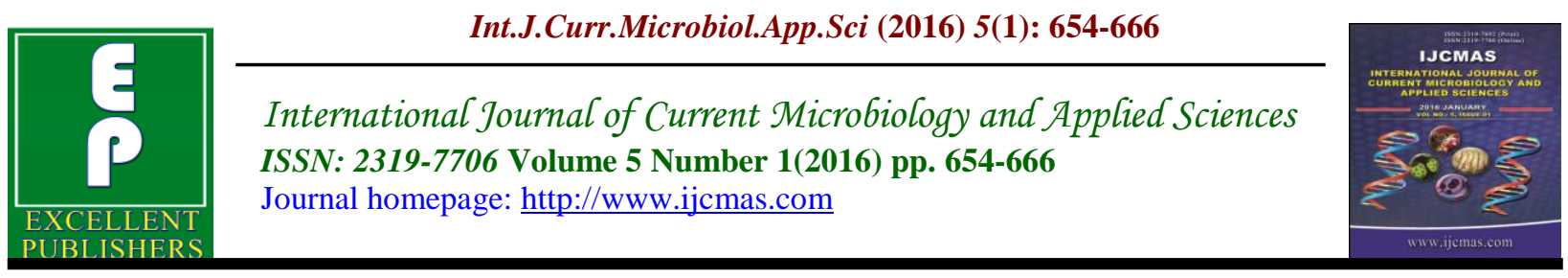

Original Research Article

http://dx.doi.org/10.20546/ijcmas.2016.501.066

\title{
Seasonal Variation in Mycoflora Population in Subtropical Forest Soil of Uttarakhand, India
}

\author{
Priya Chaudhary*, Namita Joshi and Meha Bora \\ Department of Environmental Science, Kanya Gurukul Campus, Gurukul Kangri \\ Vishwavidyalaya, Haridwar, Uttarakhand, India \\ *Corresponding author
}

\section{Introduction}

Forest soil is a rich habitat for the growth of microorganisms than other microbial habitats. Among these microorganisms, fungi are one of the dominant groups present in soil. Soil fungi are microscopic plant-like cells that grow in long threadlike structures or hyphae that make a mass called mycelium. The mycelium absorbs nutrients from the roots it has colonised, surface organic matter or the soil. It produces special hyphae that create the reproductive spores.
Fungi live, multiply and die or disintegrate in the soil and thus they provide rich organic matter, which could be recycled as plant nutrition. This developed humus complex is a natural fertilizer mixed with soil and plays a very important role in the composition of soil (Rane and Gandhe, 2006).

Majority of the fungi are free living, saprophytic or parasitic widely distributed in soil, which may vary with the soil type .It has been estimated that 1.5 million fungal 
species are present in natural ecosystems, but only $5-10 \%$ have been described formally (Hawksworth, 2001). Schmit and Mueller (2007) estimated that there is a minimum of 7, 12,000 fungal species worldwide. The actual number of fungi is still unknown; however, only 5-13\% of the total estimated global fungal species have been described (Wang et al., 2008).

Soil fungi are a major group of organisms responsible for controlling the amount of nutrient cycling and for controlling the amount of nutrient available to plants (Hernot \& Robertson 1994; Singh \& Rai 2004; Jain et al., 2005). They can decompose the plant and animal residues entering the soil and convert them into soil organic matter, which influences on soil physical, chemical and biological properties and on creating a complimentary medium for biological reactions and life support in the soil environment (Olson et al., 2000).

Soil fertility status is dependent upon soil microbial component and their mediated processes (Lynch, 1984). Therefore, it was considered imperative to investigate the seasonal variation in mycofloral population of forest soil and their relation with some important physico-chemical parameters of soil from Motichur and Chilla forest ranges of Rajaji national park, Uttarakhand.

\section{Materials and Methods}

\section{Description of the Study Area}

The Chilla and Motichur forest ranges together constitutes the study area. This is located in Rajaji National Park $\left(29^{\circ} 15^{\prime}\right.$ to $30^{\circ} 31^{\prime}$ north latitude, $77^{\circ} 52^{\prime}$ to $78^{\circ} 22^{\prime}$ east longitude) spread over an area of 820.42 $\mathrm{km}^{2}$ in and around the shivalik foothills, which lies between the lesser Himalayas and the upper Gangetic plains . The shivalik hills offer the most prominent geomorphic features of this tract. The river Ganges has cut across these hills at Haridwar.

The Chilla forest range of Rajaji national park lies to the east of river Ganges and is attatched to the Garhwal forest division while the Motichur area of Rajaji lies to the west of the river. The study site falls in the subtropical moist deciduous forest type. The soil from both the forest ranges selected for this study. The climate of the study area is like the climatic conditions of plain areas of Uttarakhand. Because of its vicinity to outer Himalayan hills climate conditions become moderate. It varies from subtropical in the plains to temperate in higher hills. Important associated tree species, shrub and herbs found in the study area were: Shorea robusta, Tectona grandis, Acacia catechu, Dalbergia sisso and Bombax ceiba, Zizyphus jujuba, Melotus sp. and Adathora vesica. The climate of the area is quite distinct in a year and represents three different seasons viz. Winter: extends about November to February, Summer: starts from March and extends upto June and Monsoon: usually breaks during the middle June and continues till October.

\section{Collection of Soil Samples}

Soil sampling was performed over a period of 24 months from July 2011 to June 2013 at both the sites. Soil was sampled from $5 \mathrm{dug}$ pits $(25 \times 25 \times 40 \mathrm{cms})$ along a random transect on a regular monthly basis upto $30 \mathrm{~cm}$. The soil samples collected were air dried and sieved through a $2 \mathrm{~mm}$ sieve and stored for subsequent analysis (Jackson, 1958; Anderson and Ingram, 1993).

\section{Analysis of Soil Physico-chemical Parameters}

Standard procedures were followed in analyzing the soil samples. The average soil temperature was measured using soil 
thermometer and moisture content of fresh soil samples was determined after oven drying them at $105^{\circ} \mathrm{C}$ and expressed as a percentage of weight of the soil samples. Soil $\mathrm{pH}$ was measured using digital $\mathrm{pH}$ meter. Organic carbon was determined following the wet digestion (Walkely and Black, 1934) and Total nitrogen was determined by Kjeldahl method (Trivedy and Goel, 1986).

\section{Isolation and Identification of Soil Mycoflora}

For isolation and estimation of fungal CFU's, serial dilution agar plating technique was adopted (Aneja, 1993) followed by Martin's agar and $10^{5}$ dilution .Dilutions are usually made in multiples of ten.

A single dilution was calculated as follows: Dilutions $=$ Volume of the sample/ Total number of the sample and the dilutents

The culture plates were prepared using horizontal laminar air flow system for mycological analysis. The plates were incubated at $25 \pm 2 \mathrm{C}$ for 4-7 days in incubator. Three replicates were maintained in each case.

Pure colonies were then transferred to PDA slants, overlaid with mineral oil and stored at $4{ }^{\circ} \mathrm{C}$ in refrigerator for further identification. After incubation the colonies on plates were counted with naked eye or with the help of electronic colony counter.

Colony forming units and Relative occurrence were calculated as follows:

\section{Colony forming units (CFU's)}

CFU's ( $\mathrm{g}^{-1}$ dry soil)

$=\underline{\text { Average number of colonies }} \mathrm{X}$ Dilution factor Dry weight of soil

\section{Relative occurrence}

Relative Occurrence $(\%)=$

Average number of colonies of a species X 100 Average no of colonies of all the fungal species

The different fungal isolates were identified by the colour, shape, size, of their conidia, mycelium and other description given by Watanabe (2002); Barnett and Hunter (1998). Fungi that did not produce spores and did not show distinct morphological characters for identification were considered as 'unidentified $\mathrm{sp}$ '.

\section{Statistical Analysis}

The statistical analysis was carried out with the help of Microsoft Office Excel 2007. Correlation coefficients ( $r$ ) between fungal population and various physico-chemical characteristics were analysed by using Pearson's correlation coefficient. $P$ values $<0.01$ and $<0.05$ were considered as significant. The objective of statistical analysis was to determine any significant differences among the parameters analyzed during the experimental process.

\section{Results and Discussion}

\section{Physico-Chemical Analysis}

Soil physico-chemical properties have long been considered to exert great influence on the distribution, growth and development of trees. Tree cover in turn, influences the improvement of physico-chemical properties of soil. Important physico-chemical properties of forest soils include temperature, moisture content, $\mathrm{pH}$, organic matter and nitrogen, etc. The physical properties of forest soils affect every aspect of soil fertility and productivity (Sheikh and Kumar, 2010). Results of the physicochemical parameters are presented in Table 1. 


\section{Temperature}

Soil temperature is an important physical property that regulates most of the physical, chemical, and biological processes of the soil, and the physiological processes of soil organisms and forest plants. In the present study, the mean values of temperature were recorded higher in summers season and lower in winter season in both the forest ranges .In the month of June, the temperature increased due to an increasing intensity of the sunshine .The reason for the decrease afterwards is that from the beginning of the second week of July, raining started due to that the temperature as well as the temperature of soil decreased.

\section{Soil Moisture Content}

Moisture content is known to be the primary contributing factor for the growth of fungi. Principle source of soil water is rainfall. Some of waterfalls during rain lost as runoff, the remaining goes on or percolates into the ground. Seasonally, in the present study the mean values of soil humidity and moisture content were reported higher in rainy season followed by winter and summer season in both the forest ranges.

This is due to the significant amount of rainfall. The rainfall affects the air temperature, the temperature of the soil surface and other parameters such as moisture contents of the soil and relative humidity. The values of moisture content $(9.92 \%$ and $8.02 \%)$ recorded by Nazir and Netajini (2014) under Shorea robusta and Tectona grandis plantation in Dehradun region of Uttarakhand falls under the range recorded in the present study in both the forest ranges.

\section{pH}

It has been reported that forest soils should be slightly acidic for nutrient supply to be balanced (Leskiw, 1998). Soil pH influences nutrient uptake and tree growth. The availability of many plant nutrients in the soil changes as a result of reactions in the soil, which are largely controlled by soil $\mathrm{pH}$. Trees may or may not be able to use nutrients because of these reactions. Soils with a $\mathrm{pH}$ of 6.0-7.0 typically have high concentrations of available nutrients (Williston and LaFayette, 1978).

In the present study, the $\mathrm{pH}$ was ranged from $6.20 \pm 0.249$ to $6.29 \pm 0.251 ; 6.15 \pm 0.248$ to $6.35 \pm 0.252$ in Motichur and Chilla respectively. Value of $\mathrm{pH} \quad(6.40 \pm 0.01)$ recorded by Chaudhary and Joshi (2013) in Motichur and Chilla forest range were similar to the results of the present study.

\section{Organic Carbon}

Soil organic carbon represents a major pool of carbon within the biosphere. According to Velayeutham et al., (1998) to sustain the quality and productivity of soils, the knowledge of organic carbon in terms of its amount and quality in soils is essential. Soil organic carbon also serves as an important source of energy for soil mycoflora. The mean values of organic carbon were ranged from: $1.68 \pm 0.129 \%$ to $2.03 \pm 0.143 \%$ and from $1.35 \pm 0.127 \%$ to $1.73 \pm 0.131 \%$ in Motichur and Chilla forest range respectively. Higher values of organic carbon were recorded in rainy season as the decomposition of leaf litter takes place at faster rates in rainy season and nutrients released into the soil.

\section{Nitrogen}

Nitrogen is an essential element for the development of cells in fungi. Soil $\mathrm{N}$ is supposed to be the most limiting nutrient in a majority of ecosystems (Fenn et al., 1998). The values of total $\mathrm{N}$ varied significantly in 
different forest types. Although $\mathrm{N}$ is mostly present in the form of nitrates in the soil, which is very mobile and get moved freely with moisture (Gupta and Sharma, 2008).

The values of total nitrogen in the study area were ranged from $0.21 \pm 0.045 \%$ to $0.24 \pm 0.049 \%$ and $0.25 \pm 0.050 \%$ to $0.28 \pm 0.053 \%$ in Motichur and Chilla forest range respectively. The availability of $\mathrm{N}$ depends to a large extent on the amount and properties of organic matter (de Hann, 1977). As $\mathrm{C}$ and $\mathrm{N}$ are intimately linked and primary source of $\mathrm{C}$ and $\mathrm{N}$ is found in the soil as an organic matter, in the form of plants and animal's debris (Aber and Melillo, 1991).

Table.1 Physico-chemical Characterization of Soil in Motichur and Chilla Forest Range (All Values are Mean \pm S.E. of 10 Observations each)

\begin{tabular}{|l|l|l|l|l|l|l|}
\hline \multicolumn{1}{|c|}{ Sites } & \multicolumn{3}{c|}{ Motichur Forest Range } & \multicolumn{2}{c|}{ Chilla Forest Range } \\
\hline $\begin{array}{l}\text { Parameters } \\
\left.\text { Temperature } \mathbf{(}^{\mathbf{0}} \mathbf{C}\right)\end{array}$ & \multicolumn{1}{c|}{ Rainy } & Winter & Summer & Rainy & Winter & Summer \\
\hline Moisture Content (\%) & $12.87 \pm 0.467$ & $17.88 \pm 0.422$ & $22.37 \pm 0.472$ & $21.77 \pm 0.466$ & $17.97 \pm 0.423$ & $23.85 \pm 0.487$ \\
\hline pH & $6.23 \pm 0.249$ & $9.15 \pm 0.313$ & $9.62 \pm 0.310$ & $10.15 \pm 0.321$ & $8.65 \pm 0.293$ & $9.25 \pm 0.303$ \\
\hline Organic Carbon (\%) & $2.03 \pm 0.143$ & $6.20 \pm 0.249$ & $6.29 \pm 0.251$ & $6.16 \pm 0.248$ & $6.15 \pm 0.248$ & $6.35 \pm 0.252$ \\
\hline Total Nitrogen (\%) & $0.24 \pm 0.049$ & $0.21 \pm 0.045$ & $0.22 \pm 0.047$ & $0.28 \pm 0.053$ & $0.25 \pm 0.050$ & $0.27 \pm 0.052$ \\
\hline
\end{tabular}

S.E. $=$ Standard Error

Table.2 Composition of Soil Mycoflora in Different Forest Ranges

\begin{tabular}{|c|c|c|}
\hline Name of fungal species & Motichur Forest Range & Chilla Forest Range \\
\hline $\begin{array}{l}\text { Ascomycotina } \\
\text { Botrytis cinerea }\end{array}$ & $\checkmark$ & - \\
\hline \multicolumn{3}{|l|}{ Deuteromycotina } \\
\hline \multirow{6}{*}{$\begin{array}{l}\text { Alternaria alternata } \\
\text { Aspergillus clavity } \\
\text { Aspergillus flavus } \\
\text { Aspergillus fumigatus } \\
\text { Aspergillus niger } \\
\text { Aspergillus parasiticus }\end{array}$} & $\checkmark$ & $\checkmark$ \\
\hline & $\checkmark$ & $\checkmark$ \\
\hline & $\checkmark$ & $\checkmark$ \\
\hline & $\checkmark$ & $\checkmark$ \\
\hline & $\checkmark$ & $\checkmark$ \\
\hline & $\checkmark$ & $\checkmark$ \\
\hline \multirow{5}{*}{$\begin{array}{l}\text { Chrysosporium sp. } \\
\text { Cladosporium sp. } \\
\text { Curvularia affinis } \\
\text { Curvularia brachyspora } \\
\text { Fusarium trichothecioides }\end{array}$} & $\checkmark$ & - \\
\hline & $\checkmark$ & - \\
\hline & $\checkmark$ & $\checkmark$ \\
\hline & $\checkmark$ & $\checkmark$ \\
\hline & $\checkmark$ & - \\
\hline \multirow{2}{*}{$\begin{array}{l}\text { Gliocladium roseum } \\
\text { Gliocladium viride }\end{array}$} & $\checkmark$ & - \\
\hline & $\checkmark$ & - \\
\hline \multirow{2}{*}{$\begin{array}{l}\text { Helminthosporium sp. } \\
\text { Penicillium ochraceum }\end{array}$} & $\checkmark$ & $\checkmark$ \\
\hline & $\checkmark$ & - \\
\hline \multirow{2}{*}{ Trichoderma sp. } & - & $\checkmark$ \\
\hline & $\checkmark$ & $\checkmark$ \\
\hline $\begin{array}{l}\text { Zygomycotina } \\
\text { Mucor jansseni }\end{array}$ & $\checkmark$ & - \\
\hline Unidentified sp. & $\checkmark$ & - \\
\hline Total Present & 19 & 11 \\
\hline
\end{tabular}


Table.3 Relative Occurrence of the Fungal Species of Soil in Motichur and Chilla Forest Range (All values are Mean \pm S.E. of 24 Observations each)

\begin{tabular}{|c|c|c|c|c|c|c|}
\hline Sites & \multicolumn{3}{|c|}{ Motichur Forest Range } & \multicolumn{3}{|c|}{ Chilla Forest Range } \\
\hline$\underbrace{\text { Seasons }}_{\text {Genera/Species }}$ & Rainy & Winter & Summer & Rainy & Winter & Summer \\
\hline Alternaria alternata & $13.12 \pm 0.166$ & $7.40 \pm 0.113$ & $12.50 \pm 0.147$ & $2.86 \pm 0.070$ & - & - \\
\hline Aspergillus clavity & $7.89 \pm 0.117$ & $7.40 \pm 0.113$ & $16.75 \pm 0.171$ & $5.71 \pm 0.100$ & $3.22 \pm 0.075$ & - \\
\hline Aspergillus flavus & $7.89 \pm 0.117$ & $7.40 \pm 0.113$ & $10.50 \pm 0.135$ & $8.57 \pm 0.122$ & $9.67 \pm 0.130$ & $3.03 \pm 0.073$ \\
\hline Aspergillus fumigatus & $10.52 \pm 0.135$ & $3.70 \pm 0.080$ & $9.37 \pm 0.128$ & $22.85 \pm 0.199$ & $16.12 \pm 0.167$ & $15.15 \pm 0.162$ \\
\hline Aspergillus niger & $7.89 \pm 0.117$ & $18.51 \pm 0.179$ & $6.25 \pm 0.104$ & $14.28 \pm 0.173$ & $12.90 \pm 0.150$ & $12.12 \pm 0.145$ \\
\hline Aspergillus parasiticus & $9.20 \pm 0.121$ & $7.40 \pm 0.113$ & $6.25 \pm 0.104$ & $11.42 \pm 0.141$ & $16.12 \pm 0.167$ & $12.12 \pm 0.145$ \\
\hline Botrytis cinerea & - & $7.40 \pm 0.113$ & - & - & - & - \\
\hline Chrysosporium sp. & - & $7.40 \pm 0.113$ & - & - & - & - \\
\hline Cladosporium sp. & - & $3.70 \pm 0.080$ & - & - & - & - \\
\hline Curvularia affinis & $7.89 \pm 0.117$ & - & $12.50 \pm 0.147$ & $2.85 \pm 0.070$ & $12.90 \pm 0.150$ & $12.12 \pm 0.145$ \\
\hline Curvularia brachyspora & $7.89 \pm 0.117$ & $3.70 \pm 0.080$ & $12.50 \pm 0.147$ & $8.57 \pm 0.122$ & $12.90 \pm 0.150$ & $12.12 \pm 0.145$ \\
\hline Fusarium trichothecioides & - & $3.70 \pm 0.080$ & - & - & - & - \\
\hline Gliocladium roseum & $3.95 \pm 0.085$ & - & - & - & - & - \\
\hline Gliocladium viride & $2.66 \pm 0.072$ & - & - & - & - & - \\
\hline Helminthosporium sp. & $10.52 \pm 0.135$ & - & $12.50 \pm 0.147$ & $17.14 \pm 0.173$ & $3.22 \pm 0.075$ & $9.09 \pm 0.126$ \\
\hline Mucor jansseni & - & $7.40 \pm 0.113$ & - & - & - & - \\
\hline Penicillium ochraceum & - & $7.40 \pm 0.113$ & - & - & - & - \\
\hline Rhizoctonia sp. & & & & - & $9.67 \pm 0.130$ & $15.15 \pm 0.162$ \\
\hline Trichoderma sp. & $8.68 \pm 0.135$ & $7.40 \pm 0.113$ & $3.12 \pm 0.074$ & $5.71 \pm 0.100$ & $3.22 \pm 0.075$ & $9.09 \pm 0.126$ \\
\hline
\end{tabular}

S.E. = Standard Error

Table.4 Correlation Analysis between Fungal Species and Some Physico-Chemical Parameters of Soil in Motichur Forest Range ( $\mathrm{n}=3)$

\begin{tabular}{|c|c|c|c|c|c|}
\hline $\begin{array}{c}\text { Parameters } \\
\text { Genera/Species }\end{array}$ & Temp & MC & pH & $\mathbf{O C}$ & $\mathbf{N}$ \\
\hline Botrytis cinerea & $-0.995 * *$ & -0.533 & -0.756 & -0.703 & -0.756 \\
\hline Alternaria alternata & 0.877 & 0.163 & 0.442 & 0.924 & $0.951 *$ \\
\hline Aspergillus clavity & 0.622 & $1 * *$ & $0.959 *$ & -0.219 & -0.143 \\
\hline Aspergillus flavus & 0.689 & $0.994 * *$ & $0.983 *$ & -0.119 & -0.043 \\
\hline Aspergillus fumigatus & $0.966 *$ & 0.393 & 0.643 & 0.807 & 0.850 \\
\hline Aspergillus niger & $-1 * *$ & -0.633 & -0.831 & -0.611 & -0.670 \\
\hline Aspergillus parasiticus & 0.263 & -0.598 & -0.339 & 0.916 & 0.882 \\
\hline Chrysosporium sp. & $-0.995 * *$ & -0.533 & -0.756 & -0.703 & -0.756 \\
\hline Cladosporium sp. & $-0.995 * *$ & -0.533 & -0.756 & -0.703 & -0.756 \\
\hline Curvularia affinis & $0.963 *$ & 0.805 & 0.943 & 0.396 & 0.465 \\
\hline Curvularia brachyspora & 0.901 & 0.897 & $0.987 *$ & 0.227 & 0.301 \\
\hline Fusarium trichothecioides & $-0.995 * *$ & -0.533 & -0.756 & -0.703 & -0.756 \\
\hline Gliocladium roseum & $0.998 * *$ & 0.762 & 0.427 & 0.217 & 0.029 \\
\hline Gliocladium viride & 0.163 & -0.467 & -0.790 & $1 * *$ & $0.982 *$ \\
\hline Helminthosporium sp. & $0.999 * *$ & 0.652 & 0.844 & 0.591 & 0.651 \\
\hline Penicillium ochraceum & $-0.995 * *$ & -0.533 & -0.756 & -0.703 & -0.756 \\
\hline Trichoderma sp. & -0.191 & -0.891 & -0.720 & 0.644 & 0.584 \\
\hline Mucor jansseni & $-0.995 * *$ & -0.533 & -0.756 & -0.703 & 0.756 \\
\hline
\end{tabular}

Temp $=$ Temperature; $\mathrm{MC}=$ Moisture content; $\mathrm{OC}=$ Organic carbon; $\mathrm{N}=$ Nitrogen

*Correlation is significant at the 0.05 level, ** Correlation is significant at the 0.01 level. Without asterisk statistically insignificant at these levels. 
Table.5 Correlation Analysis Between Fungal Species and Some Physico-Chemical Parameters of Soil in Chilla Forest Range ( $\mathrm{n}=3$ )

\begin{tabular}{|l|l|l|l|l|l|}
\hline \multicolumn{1}{|c|}{ Parameters } & Temp & MC & pH & OC & N \\
\hline Genera/Species & & & & & \\
\hline Alternaria alternata & $0.979^{*}$ & 0.877 & -0.261 & 0.857 & 0.877 \\
\hline Aspergillus clavity & 0.771 & 0.574 & -0.900 & 0.492 & 0.257 \\
\hline Aspergillus flavus & 0.271 & 0.006 & $-0.988^{*}$ & -0.091 & 0.338 \\
\hline Aspergillus fumigatus & $0.978^{*}$ & 0.888 & -0.596 & 0.839 & 0.675 \\
\hline Aspergillus niger & $0.972^{*}$ & 0.874 & -0.619 & 0.823 & 0.653 \\
\hline Aspergillus parasiticus & -0.686 & -0.854 & -0.376 & -0.901 & $-0.981^{*}$ \\
\hline Curvularia affinis & $-1^{* *}$ & $-0.957^{*}$ & 0.438 & -0.925 & -0.800 \\
\hline Curvularia brachyspora & $-0.997^{* *}$ & $-0.981^{*}$ & -0.346 & $-0.958^{*}$ & -0.856 \\
\hline Helminthosporium sp. & 0.943 & $0.997^{* *}$ & -0.090 & $1^{* *}$ & $0.961^{*}$ \\
\hline Rhizoctonia sp. & -0.897 & -0.747 & 0.776 & -0.679 & -0.472 \\
\hline Trichoderma sp. & 0.006 & 0.272 & 0.907 & 0.364 & 0.586 \\
\hline
\end{tabular}

Temp= Temperature; $\mathrm{MC}=$ Moisture content; $\mathrm{OC}=$ Organic carbon; $\mathrm{N}=$ Nitrogen

*Correlation is significant at the 0.05 level, ** Correlation is significant at the 0.01 level. Without asterisk statistically insignificant at these levels.

Figure.1-20 Representatives of different genera/species of soil mycoflora

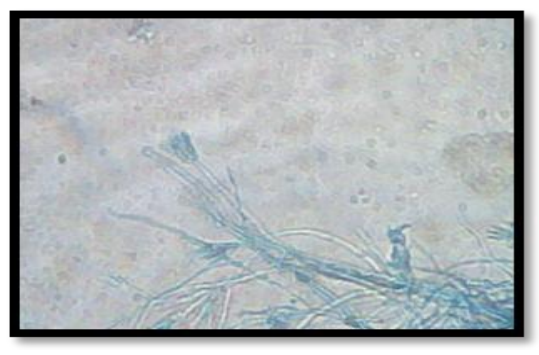

1. Botrytis cinerea

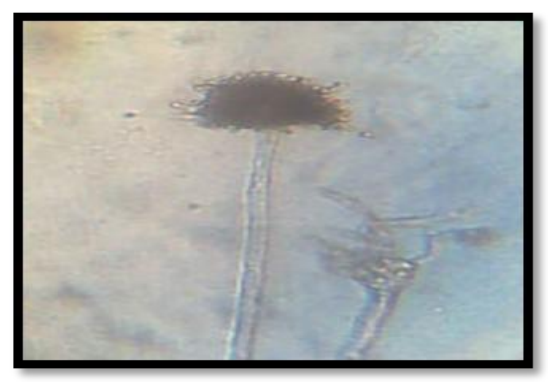

4. Aspergillus flavus

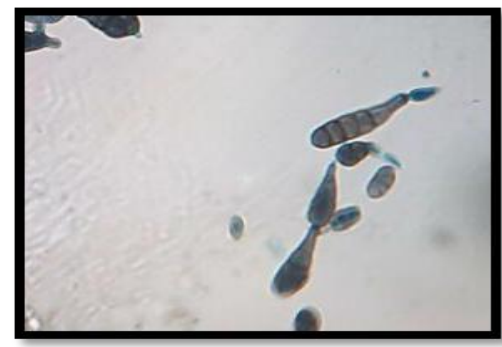

2. Alternaria alternata

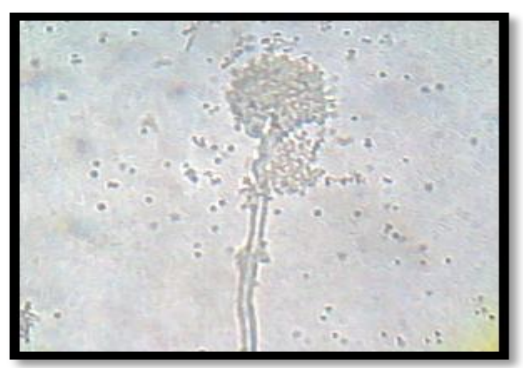

5. Aspergillus fumigatus

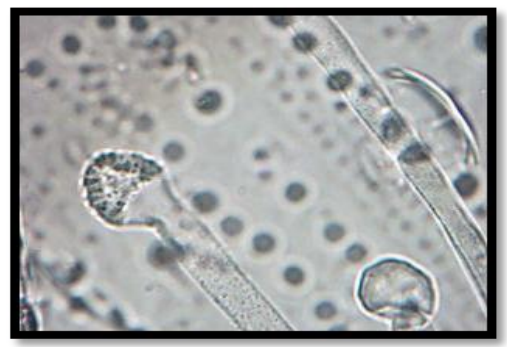

3. Aspergillus clavity

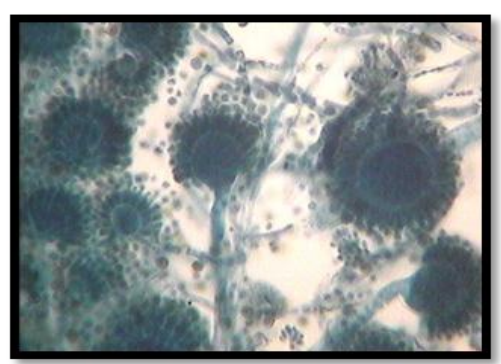

6. Aspergillus niger 


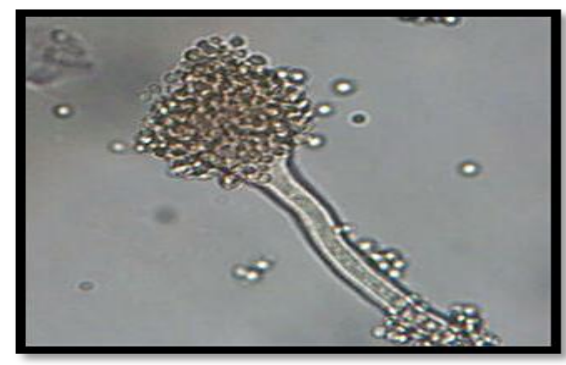

7. Aspergillus parasiticus

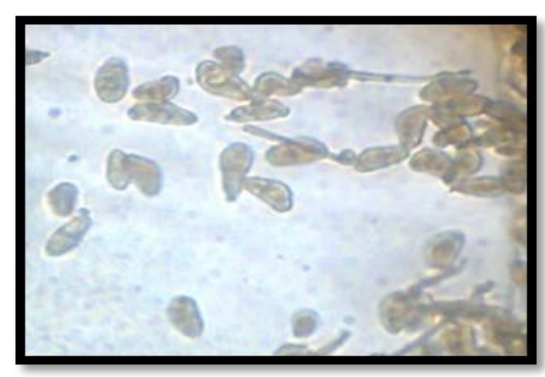

10. Curvularia affinis

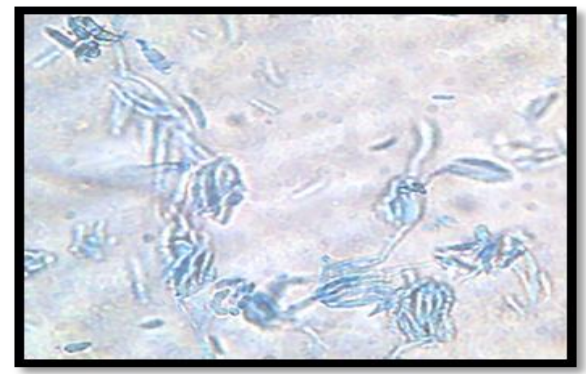

13. Gloicladium roseum

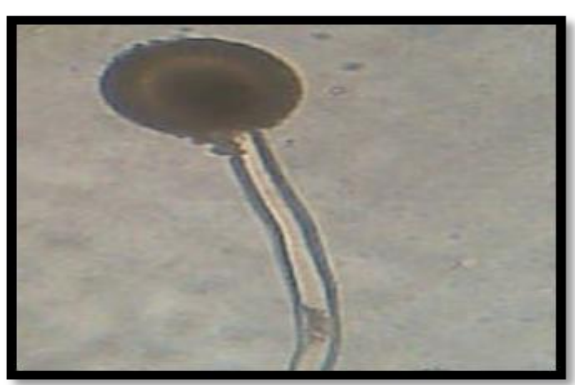

16. Mucor jansseni

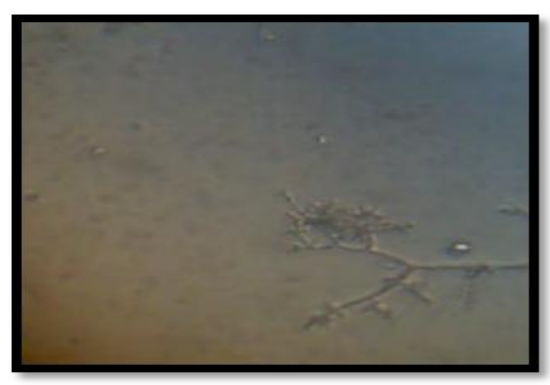

8. Chrysosporium sp.

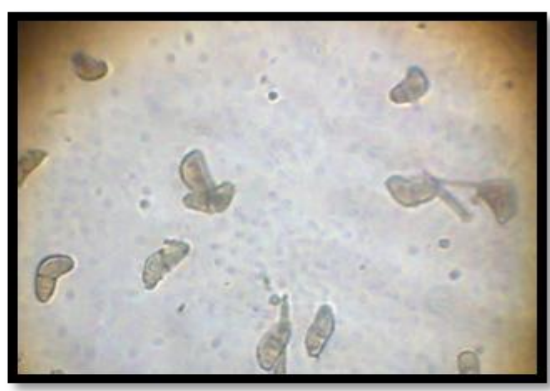

11. Curvularia brachyspora

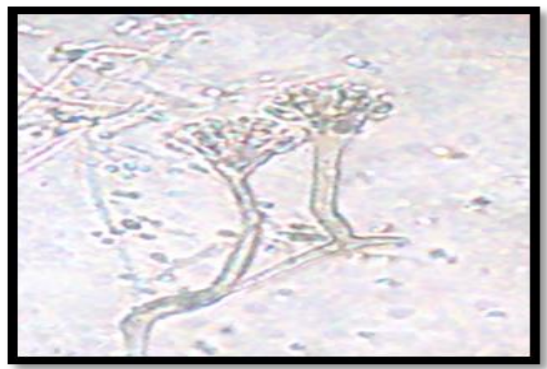

14. Gliocladium viride

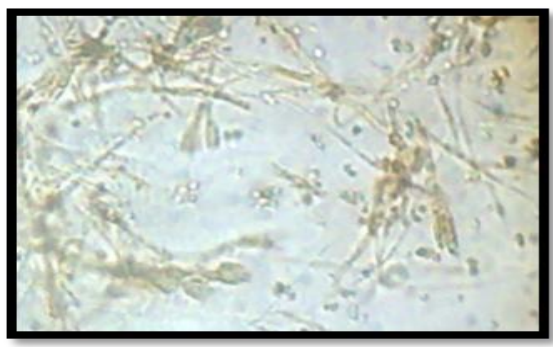

17. Penicillium ochraceum

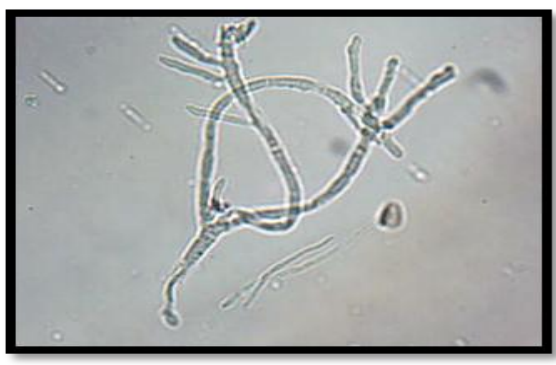

9. Cladosporium sp.

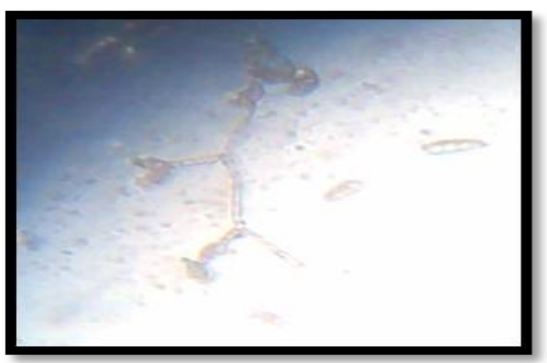

12. Fusarium trichotheciodes

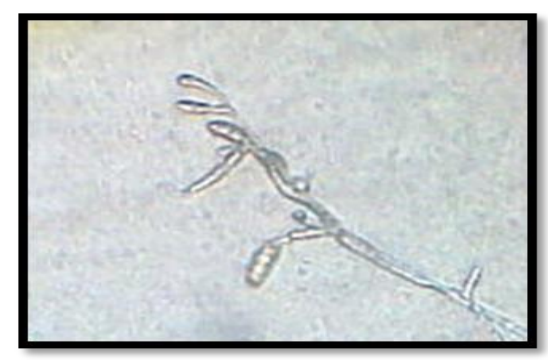

15. Helminthosporium sp.

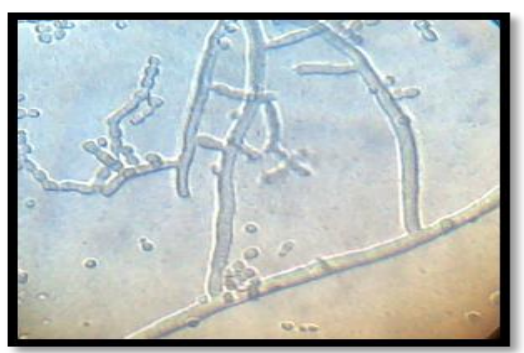

18. Rhizoctonia sp. 


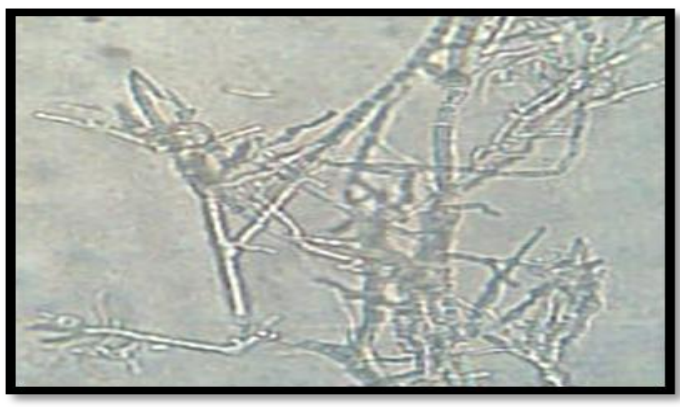

19. Trichoderma sp.

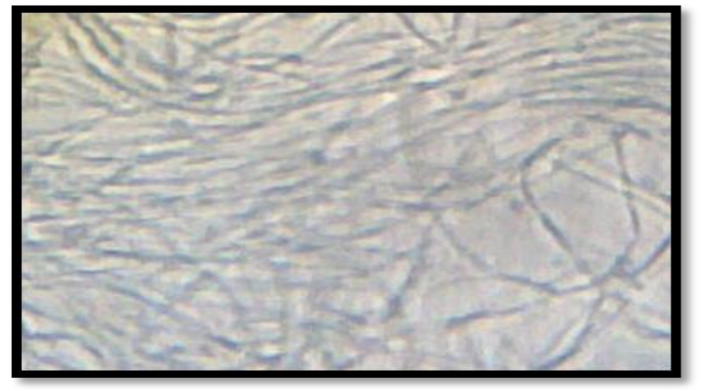

20. Unidentified sp.

Figure.21 CFU's of Soil Fungi (10 ${ }^{5}$ Dilution) in Motichur (MF) and Chilla (CF) Forest Range

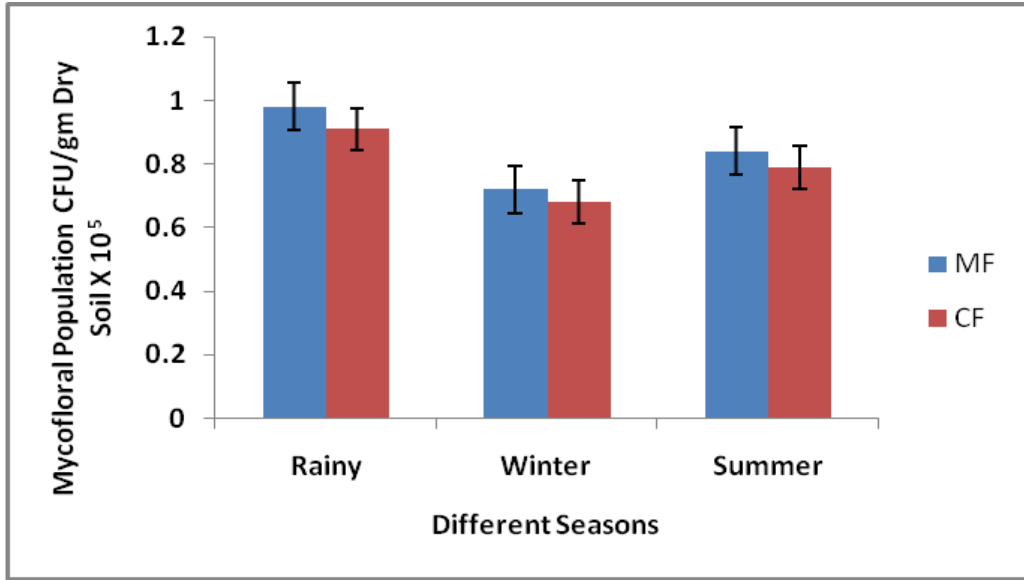

\section{Species Composition of Soil Mycoflora}

Total 20 fungal species were reported and about 19 different species belongs to three groups viz. Ascomycotina, Zygomycotina and Deuteromycotina were identified with the help of relevant literatures and one was unidentified (Figure 1-20). The fungi isolated include one species of Acomycetes, one species of Zygomycetes and remaining species were Deuteromycetes (Table 2). Out of twenty, nineteen species were isolated from Motichur forest range and eleven species were recorded from Chilla forest range.

In the present study, highest number of fungal species was recorded in soil of
Motichur forest range as compared to Chilla forest range. This is due to the presence of favourable conditions required for the growth of fungi in soil of Motichur forest range. Saravanakumar and Kaviyarasan (2010) reported sixty seven species of soil fungi belongs to 23 genera in montane wet temperate forest types of Tamil Nadu. Among them six species of Zygomycotina, two of Ascomycotina, four species of Coelomycetes and remaining five were Deuteromycetes.

\section{Colony Forming Units (CFU's)}

Seasonally, the mean values CFU's of fungi in the study area were recorded higher in rainy season followed by summer and winter 
season in both the forest ranges (Figure 21). Soil moisture content was related to the fungal CFU's and was responsible for the higher CFU's in the rainy season. Lower fungal CFU's in the dry winter season is due to the low soil moisture content. Mishra (1965) also observed that in summer months the fungal populations in soil decreases drastically, but it suddenly increases just after the onset of rain in July while April, May and June were unsuitable for the survival of fungi in soil. So, the population density of soil fungi is positively related to the moisture content of soil.

The population of fungi in the soil is quite sensitive to the amount of decomposable organic matter present. The fungi are prevalent in soils rich in plant residues where competition for food and energy is not too keen but decline rapidly as the readily decomposable material disappears (Troeh, 1993). Chaudhary and Sachar (1934), Miller et al., (1957) and Saksena and Sarbhoy (1964) reported seasonal variation in soil mycoflora and fungal population which drastically differ from season to season in a particular soil.

\section{Relative Occurrence of Soil Mycoflora}

It was observed that the some species showed highest percentage of occurrence in rainy season, some in winter season and some in summers as presented in Table 3. This pattern of relative occurrence of mycoflora was similar in both the forest ranges. This is due to the different nutritional requirements of different fungal species for their growth in different seasons.

In all the three seasons, Aspergillus sp. was common to all sites. Dominance of the genus Aspergillus sp. in the present study sites may be due to their greater sporulation capacity. This fact is also supported by Schimel, 1995.
Saravanakumar and Kaviyarasan (2010) reported that Penicillium sp. was the predominant genera followed by Aspergillus with twelve species. Similarly, Asan (1997) studied the flora of Penicillium and Aspergillus in different habitat soils in Edrine and reported twenty three species and two varieties belonging to Aspergillus and sixteen species belonging to Penicillium. Earlier reports also indicate that Aspergillus was dominant in forest soils (Galloway, 1936) and Moubasher and El-Dohlob (1970).

\section{Correlation Analysis}

Correlation analysis was performed between physico-chemical parameters and fungal species isolated in $10^{5}$ dilution, as the pure cultures were obtained in this dilution. From the results given in Table $4 \& 5$, it was observed that most of the species were significantly and negatively correlated with temperature which suggested that as the temperature increases the occurrence of fungal species decreased in the study area.

Some species showed a significant positive correlation with temperature which indicates that the fungal species are highly influenced by soil temperature. Castro et al., (2010) also found that fungal abundance was affected by temperature.

The same relationship of fungal species was observed with other parameters also viz. moisture content, $\mathrm{pH}$, organic carbon and nitrogen in both the forest ranges. As some species were positively correlated with these parameters and some were negatively correlated. Joshi et al., (2013) suggested that the physico-chemical characteristics of soil serve as an important regulating factor for the growth of fungi.

The soil $\mathrm{pH}$, organic content and water are the main factors affecting the fungal 
population and diversity (Yu et al.,2007). Organic carbon largely controls microbial growth in the natural soil (Saravanakumar and Kaviyarasan, 2010).

This study clearly indicates a marked seasonal variation in mycofloral population. Higher fungal population during rainy season which perhaps is due to prevailing favourable moisture and temperature setting during the period and other plant residues decomposed faster during rainy season and sufficient soil organic matter and humus accumulates that may have enhanced the growth of soil mycoflora in subsequent period.

\section{Acknowledgement}

We are thankful to the official staff of Rajaji national park for their cooperation during the field study. The financial support from the University Grant Commission, New Delhi is gratefully acknowledged by the first author.

\section{References}

Aber, J.D. and Melillo, J.M. 1991. Terrestrial ecosystems. Saunders College Publishing, Philadelphia.

Anderson, J.M. and Ingram, J.S.I. 1993. In: Tropical Soil Biology and Fertility: A Handbook of Methods. CAB International.30-52.

Aneja, K.R. 1993. In: Experiments in Microbiology, Plant Pathology and Biotechnology. New age international publishers. 122-123.

Asan, A. 1997. Soil fungi. Tr. J. Botany. 21: 89-101.

Barnett, H.L. and Hunter, B.B. 1998. Illustrated genera of imperfect fungi. Fourth edition. APS Press.

Castro, H.F., Ckassen, A.T., Austin, E.E.
Norby, R.J. and Schadt, C.W. 2010. Soil Microbial Community Responses to Multiple Experimental Climate Change Drivers. Applied and Environmental Microbiology. 76: 9991007.

Chaudhary, H. and Sachar, G.S. 1934. A study of fungus flora of Punjab soils. Annales. Mycol. 32: 90-110.

Chaudhary, P. and Joshi, N. 2013. Nutrient Dynamics under Different Plantations in Subtropical Forest Ecosystem. Rep Opinion .5(9):1-4.

de Hann, S. 1977. Humus, its formation, its relation with the mineral part of the soil and its significance for soil productivity. In: Organic matter studies. International Atomic Energy Agency, Vienna. 21-30.

Fenn, M.E., Poth, M.A., Aber, J.D., Boron ,J.S., Bormann, B.J., Johnson, D.W., Lenly, A.D., McNulty, S.G., Ryan ,D.F. and Stottlemeyer, R. 1998. Nitrogen excess in North American ecosystems: predisposing factors, ecosystem responses and management strategies. Ecol Appl .8(3):706-733.

Galloway, L. D. 1936. Indian soil fungi. Indian J. Agric. Sci. 6: 578-585.

Gupta, M.K. and Sharma, S.D. 2008.Effect of tree plantation on soil properties, profile morphology and productivity index I. Poplar in Uttarakhand. Ann For .16(2):209-224.

Hawksworth ,D.L.2001. The magnitude of fungal diversity: the 1.5 million species estimate revisited. Mycological Research. 105: 14221432.

Hernot, J. and Robertson, G. 1994. Vegetation removal in two soils of the humid tropics: Effect on microbial biomass. Soil Biol. Biochem. 15: $93-$ 99.

Jackson, M.L. 1958. Soil chemical analysis. Prentice - Hall of India Private 
Limited. New Delhi.

Jain, R. K., Kapur, M., Labana, S., Lal, B., Sarma, P. M., Bhattacharya, D. and Thakur, I. S. 2005. Microbial diversity: Application of microorganisms for the degradation of xenobiotics. Current Science. 89 (1): 101-112.

Joshi, P.C.; Pandey, P. and Kaushal, B.R. 2013. Analysis of some Physicochemical parameters of soil from a protected forest in Uttarakhand. Nature and Science .11(1): 136-140.

Leskiw, L.A. 1998. Land capability classification for forest ecosystem in the oil stands region. Alberia. Environmental Protection. Edmonton.

Lynch, J. M. 1984. Interactions between biological process, cultivation and soil structure. Plant and soil. 76: 307-318.

Miller, J.H.; Giddins, J.E. and Foster, A.A. 1957. A survey of fungi of forest and cultivated soils of Georgia. Mycology. 49: 779-808.

Mishra, R.R. 1965. Seasonal disrtribution of fungi in four different grass consociations of Varanasi (india). Tropical Ecology. 6:133-140.

Moubasher, A.H. and El-Dohlob, S.M. 1970. Seasonal fluctuation of Egyptian soil fungi. Trans. Br. Mycol. Soc. 54: 45-51.

Nazir, T. and Netajini, N. 2014. Economic valuation of NPK and soil vegetation interrelationship in three forest types of Dehradun. Nature and Science. 12(9):80-87.

Olson, R. K., Schoeneberger, M. M. and Aschmann, S. G. 2000. An ecological foundation for Temperate Agroforestry. In: North American Agroforestry, An Integrated Science and Practice, Eds. H. E. Garrett, W. J. Rietveld and R. F. Fisher, pp. 31-61, Wisconsin, USA: American Society of Agronomy, Madison.
Rane, G. and Gandhe, R. V. 2006. Seasonal distribution of soil fungi from forest soils of Jalgaon district. Maharashtra. Zoo's Print journal. 21(9): 2407-2409.

Saksena, R.K. and Sarbhoy , A.K. 1964. Ecology of the soil fungi of Uttar Pradesh - I. Proceedings National Institute. Sci. India. 29: 207-224.

Saravanakumar, K. and Kaviyarasan, V. 2010. Seasonal distribution of soil fungi and chemical properties of montane wet temperate forest types of Tamil Nadu. African Journal of Plant Science. 4(6):190-196.

Schmit, J.P. and Mueller, G.M. 2007. An estimate of the lower limit of global fungal diversity. Biodiversity Conservation. 16: 99-111.

Schimel, J., 1995.Ecosystem Consequences of Microbial Diversity and Community structure. Ecological studies. Chapin and Korner (Eds.), Vol. 113, Springer-Verlag, Berlin,Heidelberg, pp: 239-254.

Sheikh, M.A. and Kumar, M. 2010. Nutrient status and economic analysis of soils in Oak and Pine forests in Garhwal Himalaya. Journal of American Science. 6(2):117-122.

Singh, S. K. and Rai, J. P. N. 2004. Soil microbial population and enzyme activity related to grazing pressure in Alpine meadows of Nanda Devi Biosphere Reserve. Jr. of Environ. Biol. 25 (1):103- 107.

Trivedy, R.K. and Goyal, P.K. 1986. In: Chemical and Biological methods for water pollution studies. Third edition, Navman Prakashan. 97-112.

Troeh, F.R. and Thompson, L.M. 1993. In: Soils and soil fertility ( $5^{\text {th }}$ edition). Oxford University Press, New York.

Velayutham M., Pal, D.K., and Bhattacharyya, T. 1999. Organic carbon stock in soils of India. In: Global Climatic Change and Tropical 
Ecosystems (eds. R Lal, J.M. Kimble, H. Eswaran and B.A. Stewart), Lewis Publishers, Boca Raton, F.L. 71-96.

Walkley, A. and Black, I.A. 1934. Chromic acid titration for determination of soil organic matter. Soil Sci. 63:251.

Wang, H., Hyde, K.D. , Soytong, K. and Lin, F. 2008. Fungal diversity on fallen leaves of Ficusin northern Thailand. Journal of Zhejiang University Science. 9: 835-841.

Watanabe, T. 2002. In: Pictorial atlas of soil and seed fungi. C.R.C. Press, London.
Williston, H.L., and LaFayette, R. 1978. Species suitability and $\mathrm{pH}$ of soils in southern forests. USDA Forest Service. Southeastern Area, state and Private Forestry. Forest Management Bulletin.

Yu, C., Lv, D.G., Qin, S.J., Du, G.D. and Liu, G.C. 2007. Microbial flora in Cerasus sachalinensis rhizosphere. Chinese. J. Appl. Ecol. 18(10): 22772281.

\section{How to cite this article:}

Priya Chaudhary, Namita Joshi and Meha Bora. 2016. Seasonal Variation in Mycoflora Population in Subtropical Forest Soil of Uttarakhand, India. Int.J.Curr.Microbiol.App.Sci. 5(1): 654-666. http://dx.doi.org/10.20546/ijcmas.2016.501.066 